\title{
Trophic status of Vondo and Albasini Dams; impacts on aquatic ecosystems and drinking water
}

\author{
J. O. Odiyo $\cdot$ L. Chimuka $\cdot$ M. A. Mamali • \\ O. S. Fatoki
}

Received: 19 July 2010/Revised: 5 October 2011/Accepted: 26 December 2011/Published online: 29 February 2012

(C) CEERS, IAU 2012

\begin{abstract}
The presence and levels of major nutrients in the water from Vondo and Albasini Dams and their water treatment plants have been assessed to determine trophic status of the dams and impacts on aquatic ecosystems and drinking water. Water quality parameters particularly phosphates and nitrates are critical in assessing the trophic status. Water quality parameters linked to eutrophication and agrochemicals were analyzed. Phosphate was undetectable in both dams. The nitrate levels in Albasini and Vondo Dams which were from 1.16 to $6.65 \mathrm{mg} / \mathrm{L}$ and 0.46 to $4.19 \mathrm{mg} / \mathrm{L}$, respectively, were within and above the South African guideline for aquatic ecosystems of $2 \mathrm{mg} / \mathrm{L}$. The raw water $\mathrm{pH}$ for Vondo and Albasini Dams were from 6.20 to 7.46 and 6.35 to 8.70 , respectively, and were mostly within acceptable guidelines for aquatic ecosystems. The water transparency for Vondo and Albasini Dams were from 0.5 to $4.2 \mathrm{~m}$ and 0.4 to $0.9 \mathrm{~m}$, respectively. The levels of all other water quality parameters investigated in both dams and their WTPs mostly indicate low, rarely high and no water quality problems in aquatic ecosystems and
\end{abstract}

J. O. Odiyo ( $\square)$

School of Environmental Sciences, University of Venda, P/Bag X5050, Thohoyandou, South Africa

e-mail: John.odiyo@univen.ac.za

L. Chimuka

School of Chemistry, University of the Witwatersrand, P/Bag 3, WITS, Johannesburg, South Africa

M. A. Mamali

Department of Water Affairs, Private Bag x 9506,

Polokwane, 0700 Thohoyandou, South Africa

O. S. Fatoki

Faculty of Applied Sciences, Cape Peninsula University of Technology, Cape Town, South Africa drinking water. The low levels of total suspended solids and water transparency, the $\mathrm{pH}$ range, low to high electrical conductivity, low to acceptable dissolved oxygen levels, acceptable to high biological oxygen demand and nitrate levels for both dams indicate oligotrophic to eutrophic states. Though oligotrophic state dominates, the mixture of trophic states has been attributed to increase in urbanization and intensive agriculture.

Keywords Eutrophication - Oligotrophic and Eutrophic states - Physico-Chemical parameters - Water transparency

\section{Introduction}

Meeting water demand for domestic, industrial, agricultural and natural sustainability of ecosystem functions requires water that is not polluted with chemicals, physical and microbiological contaminants. Excessive use of agrochemicals such as fertilizers, direct discharge of effluent from wastewater treatment works into the river and illegal dumping of waste on land and into rivers contribute to water pollution. Polluted water is unsuitable for use by humans and biodiversity. Eutrophication is an indicator of excessive nutrient supply to the water body and degrades the water quality (WQ). Eutrophication is a natural problem accelerated by human activities including industrial wastewaters, agricultural runoff, nutrient loading and urban runoff. Eutrophication impairs the use of water for domestic, industrial and recreational purposes thus causing severe economic and social problems such as water quality deterioration, algal toxin productivity, taste and odour problems and decline of more desirable fish species. The cyanobacteria produces toxic substances called cynotoxins and these substances can cause the death of wild animals, 
farm livestock, pets, fish and birds. It can also cause death from liver hemorrhage or liver failure (DWAF 1996c). An example was the detection of anabaena toxins in the Waterkloof, one of the major sources of drinking water (DW) for Cape Town (Davies and Day 1998). Eutrophied water impoundment can also cause ecological impacts. For example, toxins from microcystis were identified in Zeekoei Vlei on the Cape Flats South of Cape Town in 1996, and several pet dogs died from drinking the water (Davies and Day 1998) Eutrophication surveys, conducted in the 1970s, indicated that cultural eutrophication of aquatic ecosystems (AEs) was widespread throughout South Africa (Toerin 1974; Toerien et al. 1975; Noble and Hemens 1978).

However, the most severe problems were experienced in the more developed and industrialized areas (Toerien et al. 1975). These include: rivers draining north of Johannesburg and Pretoria (The Juskei-crocodile and the Pienaars; The Shongweni Dam in Kwazulu-Natal; rivers draining south of Johannesburg into the Vaal River e.g. Klip River and Blesbokspruit; The Buffalo River in the Eastern Cape (WRC 2000). The surveys also indicated that, based on their phosphorus loading, some reservoirs (e.g. Hartbeespoort, Rietvlei and Roodeplaat) ranked as some of the most eutrophied (Walmsley et al. 1978; NIWR 1985; DWAF 2002-2003). Unpublished study by Department of Water Affairs and Forestry (DWAF) Institute for Water Quality Studies has provided evidence that eutrophication is as widespread in South Africa (SA) now as it was 25 years ago. The study also provided evidence of some positive trends in the reduction of nutrient loads and eutrophication status of several reservoirs. At the same time, some reservoirs have shown little improvement whilst others have shown deterioration (WRC 2000).

Other studies have been reported elsewhere on the trophic status of aquatic ecosystems (Rosas et al. 1993; Fatoki et al. 2003; Wendt-Rasch et al. 2004; Liou and Lo 2005; Nasrollahzadeh et al. 2008; Sager 2009; Giordani et al. 2009). Several approaches have been used to assess the trophic status such as Fuzz index model (Liou and Lo 2005), measurements of water physical-chemical parameters and rates of periphytic net primary productivity (Sager 2009), physical-chemical parameters and phytoplankton communities (Rosas et al. 1993).

In this study, physical-chemical parameters were used to assess the trophic status of Vondo and Albasin Dams on Mutshundudi and Luvuvhu Rivers, respectively. The Mutshundudi River on which Vondo Dam is situated flows over an agricultural area as a result of which the water in the dam has been identified to contain large amounts of iron and manganese (DWAF 2003). This can be linked to agrochemicals, particularly the fertilizers used in the farms. Luvuvhu River on which Albasini Dam is situated flows through an agricultural catchment and therefore its water is also expected to contain agrochemicals. DWAF (2002-2003) assessed the trophic status of South African impoundments for the period October 2002 to September 2003. The study did not assess the detailed physical and chemical water quality parameters for the impoundments. Trophic status classification for Vondo and Albasini Dams was found to be oligotrophic, which means they have less nutrients. The current study has been aimed at improving the results of the DWAF (2002-2003) study and showing the changes of trophic status with time in the two dams as potentially more agrochemicals accumulate in them. The study provided additional information on trophic status of the two dams in which the nutrient levels (trophic status) is controlled by agrochemicals leached by runoff from agricultural farms and organic waste decomposition. The study is thus important because the nutrient levels in the dams indicate the status of management of agrochemicals and organic wastes in the vicinity of the dam.

Subsequent to the current study (Harding 2008) studied trophic status of 30 selected dams in South Africa which excluded Albasini and Vondo Dams. The study determined the trophic status of the impoundments but did not include detailed assessment of physical and chemical water quality parameters. DWAF publishes seasonal (October-April) reports in their website link: (http://www.dwa.gov.za/iwqs/ eutrophication/NEMP/report/NEMPyears.htm), on water quality status for impoundments for each year which mostly do not include Albasini and Vondo Dams or are based on one or two samples. This shows that the results of the DWAF studies are mostly not detailed and representative of the true water quality status in particular seasons. The results of the current study are based on a number of continuous representative samples which give the latest detailed physical and chemical quality status of the impoundments linked to eutrophication and pollution. The results can therefore be used for present and future references in the pollution studies of the study area, and can show increase, reduction or no change. Thus, they will inform decision makers on the latest status of the water quality, importance of continuous monitoring and which parameters are of high importance during monitoring.

The main objective of this study was to determine the nutrient levels in the dams and the other water quality parameters that are critical to the assessment of the trophic status and water quality of Vondo and Albasini Dams. The analysis of the treated water was done to indicate if the treatment was done to the required level of potability. This is important in ensuring that the drinking water quality complies with the standards in order to minimize the health impacts associated with eutrophication or high nutrient levels in general. The study was conducted at the School of Environmental Sciences, University of Venda, South Africa. 


\section{Materials and methods}

Study area

The study areas, which are Vondo and Albasini Dams, are on Mutshundudi and Luvuvhu Rivers, respectively. The latitudes and the longitudes of Vondo and Albasini Dams are $22^{\circ} 56^{\prime} 47^{\prime \prime} \mathrm{S}$ and $30^{\circ} 18^{\prime} 52^{\prime \prime} \mathrm{E}$, and $23^{\circ} 06^{\prime} 14.4^{\prime \prime} \mathrm{S}$ and $30^{\circ} 05^{\prime} 45.8^{\prime \prime} \mathrm{E}$, respectively (Fig. 1). Figure 1 is a map of the study area and land use.

Sampling site and procedure

Samples were collected on monthly basis from October 2003 to October 2004. A Garmin GPS III with version 2.05 software (1997) was used to locate the sampling points. Water samples were collected in triplicate from Vondo and Albasini Dams, and Vondo and Albasini Water treatment plants (WTPs). The samples were stored in a refrigerator at low temperature (about $4^{\circ} \mathrm{C}$ ) until analyzed.

Equipment used in sampling included secchi disc, 5-m hose pipe and a bucket. 5-m hose pipe was tied at both ends with a single piece of rope about 6-7 $\mathrm{m}$ long. One end of the hose pipe was secured with a lead weight. The weighted end of the hose pipe was lowered into the water until the unweighted end was just below the surface. The hose pipe hanged in a vertical position. The attached rope was used to pull up the weighted end (forming a U-shape) until that end reached the surface. The hose pipe was then pulled out of the water and the contents transferred to the sample container.

Laboratory analysis

Physical parameters including water transparency, total suspended solids (TSS), electrical conductivity (EC) and $\mathrm{pH}$,; and chemical parameters linked to agrochemicals and/ or eutrophication including chloride $\left(\mathrm{Cl}^{-}\right)$, nitrate $\left(\mathrm{NO}_{3}{ }^{-1}\right)$, nitrite $\left(\mathrm{NO}_{2}{ }^{-1}\right)$, phosphate $\left(\mathrm{PO}_{4}{ }^{-3}\right)$, calcium $(\mathrm{Ca})$, potassium $(\mathrm{K})$, sodium $(\mathrm{Na})$, magnesium $(\mathrm{Mg})$; and, dissolved oxygen (DO) and biochemical oxygen demand (BOD) were analyzed. An EcoTherm Oven with maximum temperature of $250^{\circ} \mathrm{C}$ was used for oven-drying of salts, sample bottles and filter paper.

Analysis of nonmetals using ion chromatography (IC)

$1000 \mathrm{mg} / \mathrm{L}$ stock solutions were prepared in $100-\mathrm{mL}$ volumetric flasks from weighed amount of salt dried at $105^{\circ} \mathrm{C}$. The salts were: sodium chloride $(\mathrm{NaCl}), 1.6485 \mathrm{~g}$ for $\mathrm{Cl}^{-}$ sodium nitrate $\left(\mathrm{NaNO}_{3}\right), 1.3707 \mathrm{~g}$ for $\mathrm{NO}_{3}{ }^{-}$; sodium nitrite

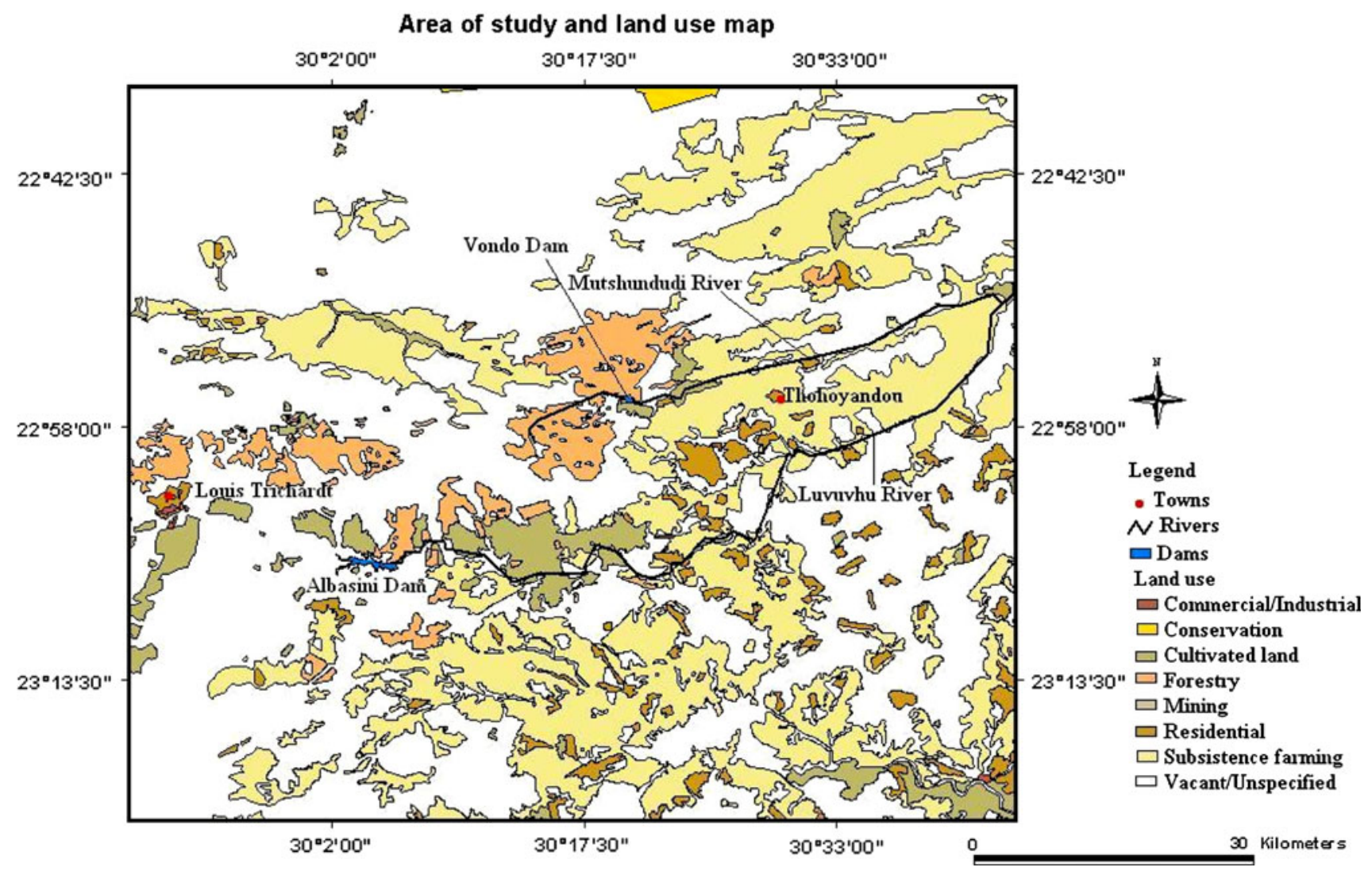

Fig. 1 Area of study and land use map 
$\left(\mathrm{NaNO}_{2}\right), 1.4998 \mathrm{~g}$ (not dried) for $\mathrm{NO}_{2}{ }^{-}$; sodium phosphate $\left(\mathrm{KH}_{2} \mathrm{PO}_{4}\right), 1.4330 \mathrm{~g}$ for $\mathrm{PO}_{4}{ }^{3-}$ and potassium sulphate $\left(\mathrm{K}_{2} \mathrm{SO}_{4}\right), 1.8184 \mathrm{~g}$ for $\mathrm{SO}_{4}{ }^{2-}$. The solutions were kept in the refrigerator at $4^{\circ} \mathrm{C}$. Combined working standard solutions of 10,5 and $1 \mathrm{mg} / \mathrm{L}$ were prepared by serial dilution. De-ionized water was used for the preparation of the standard solutions. All glassware used was washed with soap, rinsed with acidified water and de-ionized water.

The mobile phase for the ion chromatography was made by dissolving $0.5712 \mathrm{~g} \mathrm{NaHCO}_{3}$ and $0.7 \mathrm{~g} \mathrm{Na}_{2} \mathrm{CO}_{3}$ in water and diluted to $4 \mathrm{~L}$. A regenerant solution of $0.025 \mathrm{~N}$ $\mathrm{H}_{2} \mathrm{SO}_{4}$ was prepared by diluting $2.8 \mathrm{~mL}$ concentrated $\mathrm{H}_{2} \mathrm{SO}_{4}$ to $4 \mathrm{~L}$. $20 \mu \mathrm{L}$ of sample solution was filtered through a $0.45-\mu \mathrm{m}$ membrane filter to avoid blockage in the injection valve and in the capillary connection of the IC. The concentrations of chloride, nitrate, nitrite and phosphate were measured with a 761 compact ion chromatography (IC) equipped with an air-actuated 8-port injection valve with one sample loop $(20 \mu \mathrm{L})$. The analysis was done in triplicate and the mean and standard deviations of concentrations determined. The detection was done under the following ion chromatographic conditions: flow rate of $0.70 \mathrm{~mL} / \mathrm{min}$, maximum pressure of $15.0 \mathrm{mPa}$, minimum pressure of $0.1 \mathrm{mPa}$, and conductivity of $250 \mu \mathrm{s} /$ $\mathrm{cm}$. During sample analysis, a standard solution was analyzed after every ten samples to check for accuracy in the measurements. De-ionized water was also analyzed as a blank sample. Blank determination was done to confirm contamination on the analytical instrument used and no contamination was found. Peak identification was done by overlapping the peaks of the standard and that of the sample as well as spiking the samples with standard concentrations. The final water from each of the treatment plants was analyzed for each of the anions where necessary to determine their treatment to the required level of portability following similar procedures used in raw water.

Analysis of metals using atomic adsorption spectrometry (AAS)

Standard solution for calcium, sodium, magnesium and potassium were prepared using $1,000 \mathrm{mg} / \mathrm{L}$ stock solutions for the four metals. Standard solutions with different concentrations of 5,10 and $20 \mathrm{mg} / \mathrm{L}$ were prepared by pipetting calculated volume from the $1,000 \mathrm{mg} / \mathrm{L}$ into three $100-\mathrm{mL}$ volumetric flasks. The three volumetric flasks were then diluted to their marks with de-ionized water. Whatman number 1 filter papers were used to separate suspended matter from dissolved particles. Spectrometry (Spectra-AA110/220/880 Series) with flame as the atomizer was used to measure the concentrations of $\mathrm{Ca}, \mathrm{Na}, \mathrm{K}$ and $\mathrm{Mg}$ in the water samples. The instrument was calibrated using the prepared $\mathrm{Ca}, \mathrm{Mg}, \mathrm{K}$ and $\mathrm{Na}$ standard solutions. Instrument setting was performed as per manual. The calibration curves yielded good correlation with correlation coefficient $\left(\mathrm{R}^{2}\right)$ ranging from 0.9802 to 0.9943 . This implies that the instrument used was functioning properly with very good precision and reliability.

The measurements of $\mathrm{Ca}, \mathrm{Mg}, \mathrm{K}$ and $\mathrm{Na}$ concentrations for Vondo and Albasini Dams were done in triplicates and the mean and the standard deviations of concentrations were determined. The final water from each of the treatment plants was analyzed for each of the cations where necessary to determine their treatment to the required level of potability following similar procedures used in raw water.

Analysis of water transparency and TSS

A secchi disk was used to determine water transparency/ light penetration, which is the clarity of water that in turn is inversely related to its turbidity. A secchi disk was attached to a rope marked in $1 \mathrm{~m}$ intervals. The secchi disk was lowered into the water and the depths at which the disk disappeared (called secchi depths) were recorded (the depth reading on the marked rope) and provided the estimation of the water transparency.

Suspended solids were measured after the filter paper was dried to constant weight at a temperature of $100^{\circ} \mathrm{C}$. Twenty milliliter of sample was filtered to separate the suspended matter from the dissolved solids. After filtration, the filter paper was dried for once more at the temperature of $100^{\circ} \mathrm{C}$. The difference between the two weights was the total suspended solids.

\section{Analysis of $\mathrm{pH}, \mathrm{EC}, \mathrm{DO}$ and BOD}

The $\mathrm{pH}$ and EC were measured with $\mathrm{pH} / \mathrm{EC}$ Meter. Dissolved oxygen was determined immediately after sample collection using DO Meter. $\mathrm{BOD}_{5}$ was measured after 5 days using DO Meter.

\section{Results and discussion}

Water transparency/light penetration and TSS

Secchi readings for both Vondo and Albasini Dams are presented in Fig. 2a. The mean Secchi disc readings for Vondo and Albasini Dams were $2.6 \mathrm{~m}$ and $0.6 \mathrm{~m}$, respectively. Vondo and Albasini Dams can be classified as clear and turbid because the mean Secchi disc readings were greater than $0.8 \mathrm{~m}$ and fell within $0.2-0.8 \mathrm{~m}$, respectively, following the DWAF guidelines in (Van Ginkel 2001). For turbid water, the depth at which the Secchi disk can be seen decreases significantly (Davies and Day 1998). In a study 
$\mathbf{a}$
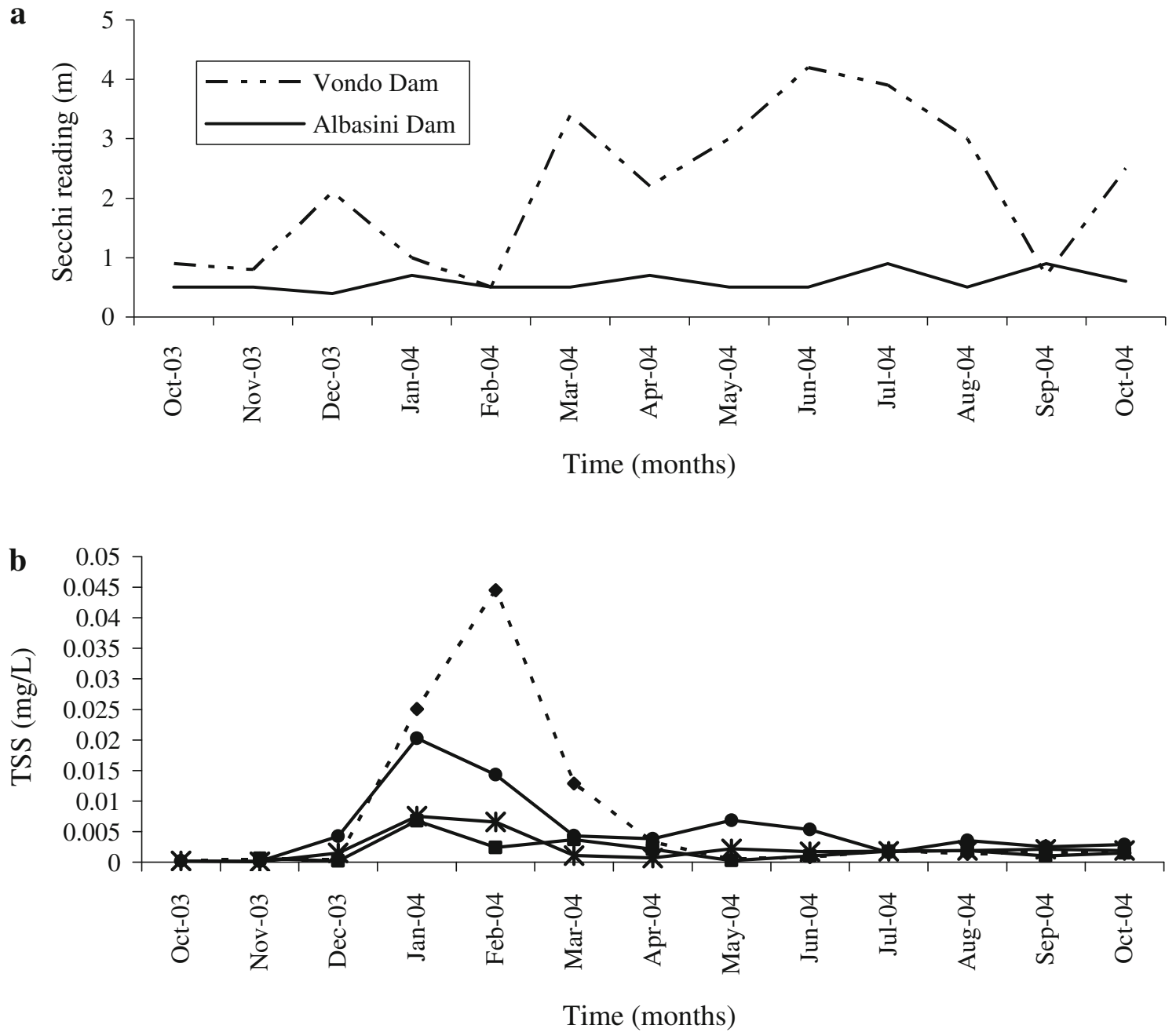

- $\multimap-\cdot$ Vondo Dam $\longrightarrow$ Albasini Dam $\longrightarrow$ Albasini WTP $\longrightarrow$ Vondo WTP

Fig. 2 a Water transparencies for Vondo and Albasini Dams. b TSS concentrations for raw water from Vondo and Albasini Dams and treated water from Vondo and Albasini WTPs from October 2003 to October 2004

on trophic status of lake Patzcuaro, Mexico by Rosas et al. (1993), the average transparencies were found to vary between 0.62- and 1.4-m Secchi depths and hence were comparable to the results of the current study.

The mean concentration of TSS from October 2003 to October 2004 for raw water from Vondo and Albasini Dams ranged from 0.2 to $44.5 \mu \mathrm{g} / \mathrm{L}$ and 0.15 to $20.25 \mu \mathrm{g} / \mathrm{L}$ respectively (Fig. 2b). The increase in TSS concentration for raw water from Vondo Dam during January to February 2004 did not exceed the Target Water Quality Range for aquatic ecosystems of $<100,000 \mu \mathrm{g} / \mathrm{L}$ (DWAF 1996c). Similarly, the TSS of Albasini Dam never exceeded the target water quality range for aquatic ecosystems. The study shows that the Secchi readings for Albasini Dam were mostly lower than Vondo Dam (Fig. 2a), which means that the clarity of Vondo Dam was generally higher than Albasini Dam. This implies that the TSS of Vondo Dam should be generally lower than that of Albasini Dam. This is generally the case except for peak rainfall months (January and February) when the TSS, though low, is higher in Vondo Dam than in Albasini Dam (Fig. 2b). The Secchi readings for these peak months are low and approximately the same for both dams (Fig. 2a), and are hence in line with the expectation.

The nutrients from agrochemicals dissolved in runoff from the farms upstream of Albasini Dam could possibly be contributing to increased algal growth that reduces light penetration and hence reduces the Secchi readings (Fig. 2a). Vondo Dam which is in upstream forested area of the Soutpansberg Mountains and in the neighbourhood of the tea estate has reduced impact of agrochemicals as the runoff is limited by vegetation except during the peak rainfall 
months. This possibly results in low algal growth and hence relatively high Secchi readings compared to Albasini Dam (Fig. 2a). The inconsistent Secchi readings throughout the year in Vondo Dam can be attributed to more sediment and nutrients carried by runoff into the dam during the rainy season (October-March). In the dry season the sediments mostly settle at the bottom of the dam leading to increased light penetration and Secchi readings.

The results show direct correlation between TSS and water transparency/light penetration and both can be used to define the turbidity or clarity of the two dams. Transparency of water relates to the depth that light penetrates into the water body. The transmission of light into the water body is important for aquatic life since the sun is the source of energy for all biological phenomena. The low concentrations of TSS for Vondo Dam indicate the clarity of water confirmed by the Secchi disc reading. The Secchi disc reading and the low TSS concentrations for Vondo Dam imply that there is sufficient light penetration and therefore photosynthesis can take place at the surface and in the deeper sections of the water impoundment. Thus, the level of oxygen is high as photosynthesis is responsible for the production of oxygen leading to low BOD. Similar behaviour possibly applies to Albasini Dam. Though the mean Secchi disk reading indicates turbid water in Albasini Dam, the range $(0.4-0.9 \mathrm{~m})$ shows that the water oscillates between turbid and clear water, indicating that the turbidity is likely to be low. This has been confirmed by low values of TSS. Turbid water reduces light penetration leading to decrease in photosynthesis, and the resultant decrease in primary production reduces food availability for aquatic organisms higher up the food chain.

Other than reducing the light penetration and lowering the rate of photosynthesis of the dam, high concentrations of TSS greater than $100 \mathrm{mg} / \mathrm{L}$ can have other effects such as clogging of fish gills, either killing them or reducing their growth rate (DAWM 1985-1994, accessed on 11 November 2005). Because the suspended solids have small sizes they may have a considerable surface area and many of them carry an electrical charge (Davies and Day 1998). As a result, a variety of dissolved substances including phosphate become adsorbed onto the surfaces of the particles and the adsorbed substances may become unavailable. This may be disadvantageous if they are valuable nutrients.

Low TSS concentrations of Vondo Dam do not exceed the target water quality range for aquatic ecosystems even during high flow periods. The Thathe Vondo Forest Plantation and the Tshivhase Tea Estate, contribute to the reduction of TSS concentration. The strip cropping of Tshivhase Tea Estate reduces the runoff velocity. Erosion is largely limited to the row-crop strips and soil removed is trapped in the next strip down slope as described by Morgan (1990). This limits the rate of suspended material from entering Vondo Dam. The TSS concentration of Albasini Dam is also low because the watershed has lots of firmly rooted vegetation that act as sponge for trapping water and soil thereby eliminating most erosion. Dense vegetation cover reduces the volume of runoff by intercepting rainfall at the canopy and thus causing high rate of infiltration. This combined with low intensity rainfall contributes to less erosive runoff. In a study by Rosas et al. (1993) rainfall was found to be the primary factor in seasonal variation of both physical and biological conditions of the lake.

The TSS concentrations for both Vondo and Albasini Dams are caused by discharge of eroded sediments by runoff from rainfall into the dams and resuspension of deposited material. When the water moves slowly the suspended sediments settle out and are deposited at the bottom of the dam and become part of the bed load. This causes the water to become clear. The low TSS in both dams is an indication of low nutrient adsorption and limited effect on nutrient availability. Thus, the concentrations of nutrients measured in the water impoundments were not adversely affected by the TSS adsorption.

The mean concentrations of TSS from October 2003 to October 2004 for treated water from Vondo and Albasini WTPs ranged from 0.2 to $6.8 \mu \mathrm{g} / \mathrm{L}$, and 0.1 to $7.5 \mu \mathrm{g} / \mathrm{L}$, respectively (Fig. 2b). The low levels of TSS in treated water in both the water treatment plants imply achievement of good drinking water quality with a possibility of no or limited micro-organisms.

\section{$\mathrm{pH}$ and $\mathrm{EC}$}

The mean $\mathrm{pH}$ values for raw water from Vondo and $\mathrm{Al}$ basini Dams from October 2003 to October 2004 ranged from 6.20 to 7.46 and 6.35 to 8.70 , respectively (Fig 3a). This indicates that the $\mathrm{pH}$ values measured in water from the two dams fall mostly in the same range. The SA target $\mathrm{pH}$ range for aquatic ecosystems is 6.5-8.5 (DWAF 1996b). pH of 6.7-8.6 can support a well-balanced fish population (Videtich and Erik 2002). Only very few fish species can tolerate $\mathrm{pH}$ of less than 5.0 or greater than 9.0 (Videtich and Erik 2002). The mean $\mathrm{pH}$ values for raw water from Vondo and Albasini Dams are thus mostly within acceptable standards.

The toxic effects of acid $\mathrm{pH}$ on fish, increases as the concentrations of calcium, chloride and sodium decreases (DWAF 1996c). Since the concentrations of calcium and chloride were found to be low but within the acceptable limits for unpolluted fresh water and the concentration of sodium was found to be significant (Mamali 2007), they are not likely to pose any toxic effects to fish.

The variation in $\mathrm{pH}$ may be as a result of photosynthesis and respiration that vary over a 24 -h period, in a productive 

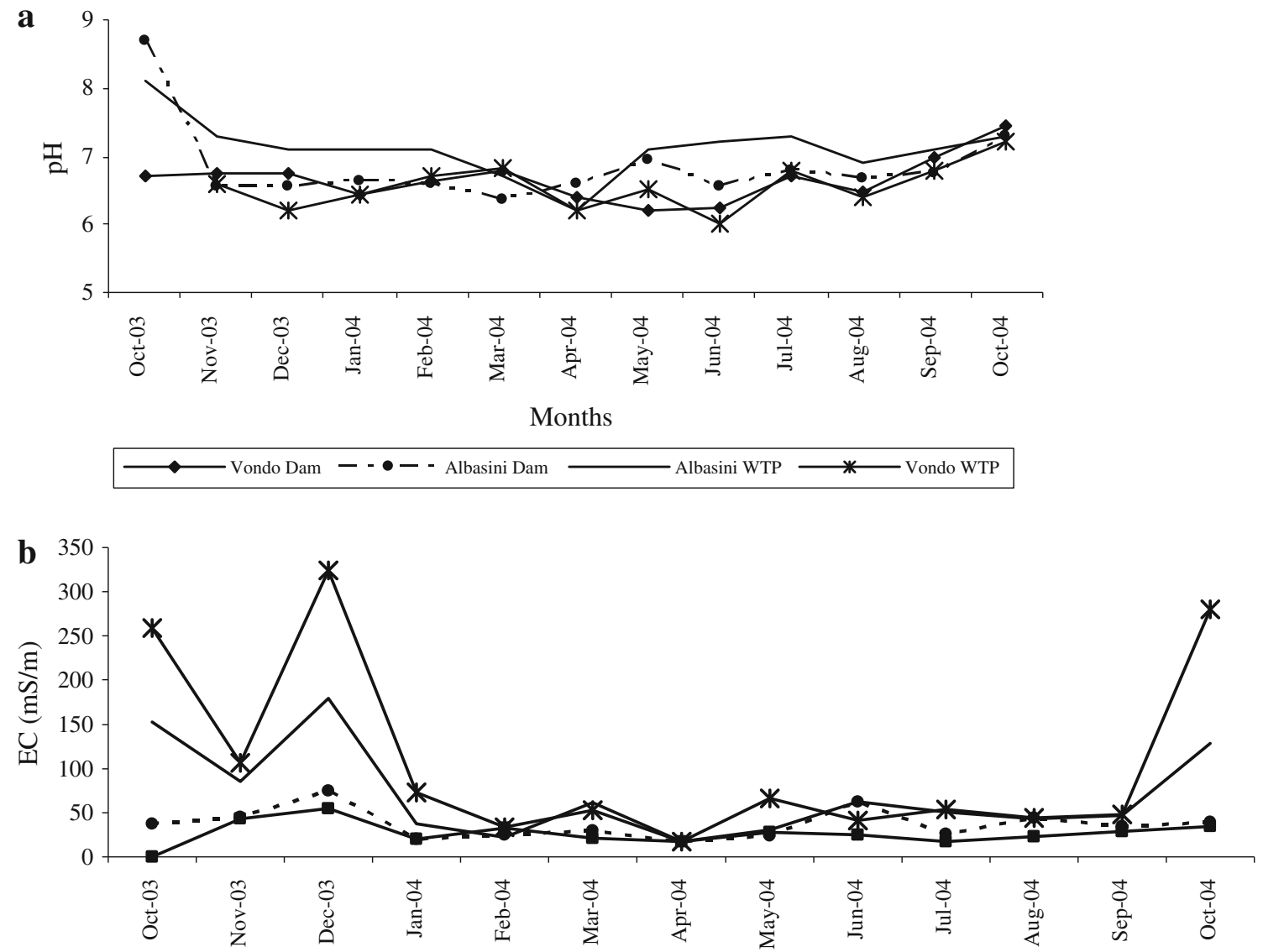

Time (months)

$\longrightarrow$ Albasini Dam - - - - Vondo Dam $\longrightarrow$ Vondo WTP $\longrightarrow$ Albasini WTP

Fig. 3 a pH values for raw water from Vondo and Albasini Dams and treated water from Vondo and Albasini WTPs from October 2003 to October 2004. b EC concentrations for raw and treated water from

water impoundment. Photosynthesis alters the carbonate/ bicarbonate equilibrium by removing $\mathrm{CO}_{2}$ from the water. Extreme rate of photosynthesis as a result of eutrophication leads to very high $\mathrm{pH}$ values. High rates of consumption of $\mathrm{CO}_{2}$ during photosynthesis drive the carbonate species equilibrium towards carbonic acid and hence to extremely low $\mathrm{pH}$ values of less than 6.5 (DWAF 1996c).

In eutrophic water impoundment where photosynthesis is high, $\mathrm{pH}$ distribution varies in a vertical direction, with the upper waters being relatively alkaline, while the lower depth where lack of sunlight reduces photosynthesis is more acidic (Horiba International Co-operation 2003, accessed on 10 November 2005). The elevation in $\mathrm{pH}$ can be caused by biological activity. The $\mathrm{pH}$ may fluctuate from 6 to 10 as a result of changing rates of photosynthesis and respiration (Horiba International Co-operation 2003, accessed on 10 Nov 2005).

The results show that the $\mathrm{pH}$ of Vondo Dam is within the recommended limit of oligotrophic water
Vondo and Albasini Dams and Vondo and Albasini WTPs from October 2003 to October 2004

impoundment. The $\mathrm{pH}$ of raw water from Albasini Dam for October 2003 of 8.70 is slightly higher than the recommended DWAF (1996b) limit for aquatic purposes. From November 2003 to March 2004 the $\mathrm{pH}$ of raw water from Albasini Dam was slightly stable. Based on the guidelines, the acidity and alkalinity would not have adversely affected the use of water for aquatic ecosystem purposes. Because of the clarity of water and the normal rate of photosynthesis throughout the two water impoundments, the $\mathrm{CO}_{2}$ consumption is not high. The variation in $\mathrm{pH}$ distribution is not vertical because the light penetrates even the deeper section of the water impoundment, unlike in eutrophic water impoundment where light is scattered by high concentration of TSS and penetrate in the upper section of the water impoundment.

The mean $\mathrm{pH}$ values for treated water from Vondo and Albasini WTPs from October 2003 to October 2004 ranged from 6.0 to 7.2 and 6.2 to 8.1 , respectively (Fig. 3a). The SA target $\mathrm{pH}$ range for domestic use is 
6.0-9.0 (DWAF et al. 1999). The mean $\mathrm{pH}$ values for treated water from Vondo and Albasini Dams are thus within acceptable standards. Based on the guidelines, the acidity and alkalinity would not affect the use of water for drinking.

The EC varied between 16.93 to $74.73 \mathrm{mS} / \mathrm{m}$ and 16.93 to $179.05 \mathrm{mS} / \mathrm{m}$ in raw water from Vondo and Albasini Dams respectively (Fig. 3b). These values fall within and exceed the SA DWAF et al. (1999) guideline for unpolluted fresh water of less than $70 \mathrm{mS} / \mathrm{m}$. High values of electrical conductivity for raw water from Albasini Dam during October to December 2003 and October 2004 may have been from the runoff containing fertilizers from the farms, mainly composed of nitrates. During April 2004 the electrical conductivities of Vondo and Albasini Dams were low indicating that major activities that impact on water were at the minimum.

Electrical conductivity provides an estimate of dissolved ionic matter in the water. Low values of specific conductance are characteristic of high quality, oligotrophic (low nutrient) impoundment (Videtich and Erik 2002). High values of specific conductance are observed in eutrophic lakes where plant nutrients (fertilizers) are in greater abundance (Videtich and Erik 2002). Therefore Albasini Dam can be classified as eutrophic for the first 3 months (October-December 2003) when the conductivity exceeded the acceptable limit. Vondo Dam can be classified as oligotrophic because of the low conductivity values. Though the conductivity in Albasini Dam during December 2003 of $179.05 \mathrm{mS} / \mathrm{m}$ exceeded the acceptable limit, the total mean concentration from October 2003 to October 2004 was within the acceptable limit. In many cases high EC values imply low quality water. Unlike Albasini Dam the use of fertilizers around Vondo Dam is not intensive and results into high quality water.

The EC varied between 16.8 to $54.8 \mathrm{mS} / \mathrm{m}$ and 17.4 to $324 \mathrm{mS} / \mathrm{m}$ in treated water from Vondo and Albasini WTPs, respectively (Fig. 3b). South African guidelines for drinking water quality indicate that health effects from EC occur only at the levels above $70 \mathrm{mS} / \mathrm{m}$ (DWAF et al. 1999). Effects may include adverse effects on infants, i.e. disturbance of salt and water balance and adverse effects on certain heart patients and individuals with high blood pressure (DWAF et al. 1999). Thus the occasional high EC in the treated water from Albasini Dam is a major threat to human health. The higher EC in treated water than dam water is caused by the anions and cations such as chlorides and alum added to water for treatment.

\section{Chloride}

The chloride concentrations ranged between $3.70-9.33 \mathrm{mg} /$ $\mathrm{L}$ and $10.7-30.2 \mathrm{mg} / \mathrm{L}$ in raw water from Vondo and
Albasini Dams respectively (Fig. 4a). The Vondo Dam values fall within the SA chloride guidelines for unpolluted fresh water of $<10 \mathrm{mg} / \mathrm{L}$ (DWAF et al. 1999). The chloride concentrations in the dam peaked in January, May and August 2004 (Fig. 4a). However, the recommended limits were never exceeded.

In both raw and final waters, Albasini Dam gave higher values of chloride throughout the studied period compared to Vondo Dam. This difference was more pronounced in October-December 2003 and August-September 2004. The Albasini Dam chloride concentrations exceeded the SA guidelines in unpolluted fresh water. These concentrations are likely to pose toxic effects to fish.

It is important to note that sodium chloride impart salty taste at $250 \mathrm{mg} / \mathrm{L}$ (DAWM 1985-1994). Criterion for the protection of aquatic life requires sodium chloride levels of less than $600 \mathrm{mg} / \mathrm{L}$ (DAWM 1985-1994). The highest concentrations of chlorides in raw water from Albasini Dam were detected from October to December 2003. The lowest concentration of $10.7 \mathrm{mg} / \mathrm{L}$ was detected in October 2004 (Fig. 4a).

Chloride comes from natural rich chloride soil and increases in concentration in the treated water after chlorination process for disinfection. Disinfection is the process of counteracting infection through the use of a disinfectant, with a chemical substance which destroys micro-organisms such as bacteria (DWAF et al. 1999).

Other possible sources of the chlorides may be agricultural runoff because of the intensive formal agricultural and human activities around Luvuvhu Valley. Horiba International Co-operation (2003) reported that every day the average person uses and disposes $10-20 \mathrm{~g}$ of salt. Therefore when high concentrations of chlorides are found, waste from daily life can be suspected too.

The chloride concentrations ranged between $3.6-8.3 \mathrm{mg} / \mathrm{L}$ and $7.88-34.46 \mathrm{mg} / \mathrm{L}$ in treated water from Vondo and Albasini WTPs respectively (Fig. 4a). The chloride concentrations in both the WTPs fell within the SA chloride guidelines for drinking water of less than $100 \mathrm{mg} / \mathrm{L}$ (DWAF et al. 1999). This implies that both Albasini and Vondo WTPs were efficiently operated especially Albasini WTP because the chloride values in raw water were high. Thus the chloride concentrations have no negative impact on drinking water quality.

Nitrate and nitrite nutrients

Nitrate concentrations in raw water from Vondo and Albasini Dams ranged between $0.46-4.19 \mathrm{mg} / \mathrm{L}$, and $1.16-6.65 \mathrm{mg} / \mathrm{L}$, respectively (Fig. 4b). These values fall within and exceed the SA nitrate guideline in unpolluted fresh water of $2 \mathrm{mg} / \mathrm{L}$ (DWAF et al. 1999). 


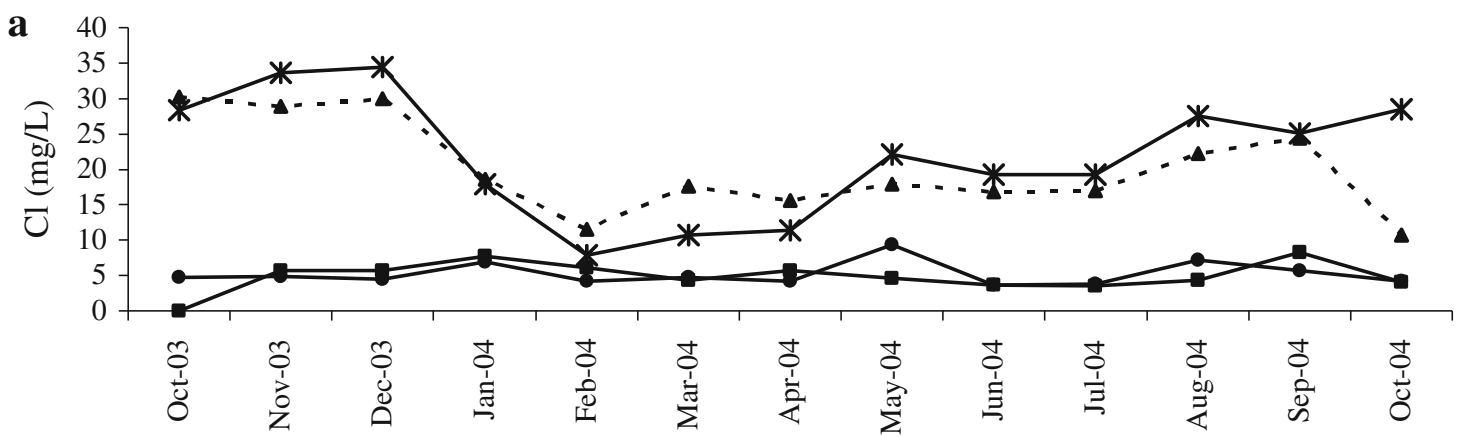

Time (months)
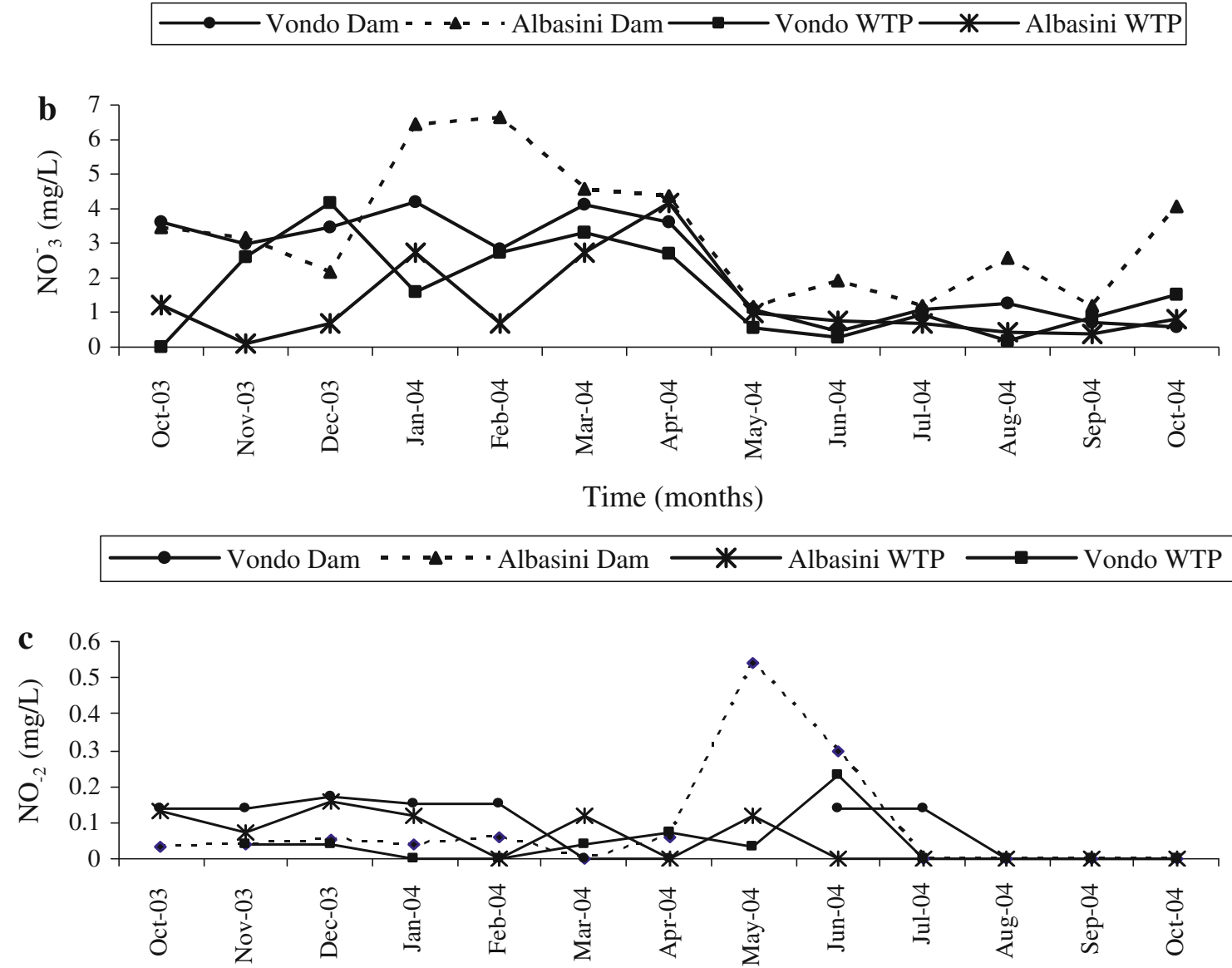

Time (months)

- - - - Vondo Dam —— Vondo WTP $\longrightarrow$ Albasini Dam $\longrightarrow$ Albasini WTP

Fig. 4 a Chloride concentrations for raw water from both Vondo and Albasini Dams and final water from Vondo and Albasini WTPs from October 2003 to October 2004. b Nitrate concentrations for raw water from Vondo and Albasini Dams and final water from Vondo and

The Environment Protection Agency (EPA) adopted the $10 \mathrm{mg} / \mathrm{L}$ standard as the maximum contamination level (MCL) for nitrate-nitrogen. In South Africa, inorganic nitrogen concentrations in unpolluted, aerobic surface water are usually below $0.5 \mathrm{mgN} / \mathrm{L}$ but may
Albasini WTPs from October 2003 to October 2004. c Nitrite concentrations for raw water from Vondo and Albasini Dams and final water from Vondo and Albasini WTPs from October 2003 to October 2004

increase to above $5-10 \mathrm{mgN} / \mathrm{L}$ in highly enriched waters (DWAF 1996c). Thus, though nitrate concentrations in Vondo and Albasini Dams exceeded the SA guideline, they were within the EPA maximum contamination limit. 
High values of nitrate concentrations in Vondo Dam were detected from October 2003 to April 2004 (Fig. 4b). From May to October 2004 the nitrate concentrations were within the SA acceptable limit for aquatic ecosystems (DWAF et al. 1999). High nitrate values in Albasini Dam were detected from October 2003 to October 2004 with only a few intervening periods with low concentrations below the SA standard guideline for unpolluted water. The highest and the lowest concentrations of $6.65 \mathrm{mg} / \mathrm{L}$ and $1.16 \mathrm{mg} / \mathrm{L}$ were detected in February and May 2004 and can be linked to high and low flows, respectively.

Since nitrate values exceeded the SA guideline for aquatic ecosystems during high flow period (wet season) and to a limited extent during low flow period (dry season), it means that the nitrogen from agriculture was released into the soil and transported into the dams during high flows. The impact of nitrates on fresh water bodies is that of enrichment or fertilization called eutrophication. Nitrates stimulate the growth of algae and other plankton, which provide food for higher organisms. An excess of nitrogen causes over-production of plankton and as they die and decompose they use up the oxygen, which causes the other oxygen dependent organisms to die.

Nitrate is one of the major inorganic nitrogen components present in water like nitrite and ammonia which are all available for uptake by algae and higher plants. High concentrations can be caused by the conversion of nitrite to nitrate by bacterial processes or nitrite oxidization to nitrate by nitrifying bacteria. Nitrate is highly leachable and readily moves with water through the soil profile (Freedman 1995). The excessive rainfall during January 2004 may have caused the nitrate to be leached below the plants root zone.

The neighborhood of Vondo and Albasini Dams are densely vegetated and decomposing plant material can cause high concentration of nitrate. This is because the abundance of plants in a particular area influences organic matter supply to the ground. Litter fall and dead plant structures cause high nitrate concentration during decomposition. High concentration of nitrate may also be caused by biological fixation which is the conversion of gaseous nitrogen to nitrate which is carried out by a variety of organisms including blue-green algae.

Nitrate concentrations in treated water from Vondo and Albasini WTPs ranged between $0.18-4.17 \mathrm{mg} / \mathrm{L}$ and 0.11-4.16 mg/L, respectively (Fig. 4b). The nitrate values for treated water fall within the (DWAF et al. 1999) guideline for drinking water of less than $20 \mathrm{mg} / \mathrm{L}$ and thus nitrate has no negative impact on human health.

The nitrite concentrations for raw water from Vondo and Albasini Dams ranged between trace (undetectable) to $0.54 \mathrm{mg} / \mathrm{L}$ and trace to $0.17 \mathrm{mg} / \mathrm{L}$ from October 2003 to October 2004, respectively (Fig. 4c). The nitrite concentrations for Albasini and Vondo raw water do not exceed the SA guidelines for nitrite in unpolluted freshwater (DWAF et al. 1999). The low concentrations may be caused by the transformation of nitrite into nitrate thereby increasing the nitrate concentrations for Vondo and Albasini Dams. Mostly the nitrite concentrations in raw water from Albasini Dam were high just like the nitrate above. This does explain a link between nitrite and nitrate concentrations and including their possible sources.

Nitrites can produce a serious condition in fish called "brown blood disease" (Freedman 1995). Nitrite/nitrogen levels below $90 \mathrm{mg} / \mathrm{L}$ have no effect on warm water fish (DAWM 1985-1994, accessed on 09 September 2006). High nitrite levels are known to be present in polluted, turbid waters. Due to low concentration of TSS in the two water systems, that represents the clarity or turbidity of water, the nitrite concentrations also tend to be low.

The nitrite concentrations for treated water from Vondo and Albasini WTPs ranged between trace to $0.23 \mathrm{mg} / \mathrm{L}$ and trace to $0.16 \mathrm{mg} / \mathrm{L}$ from October 2003 to October 2004 respectively (Fig. 4c). The nitrite concentrations for both the WTPs do not exceed the SA guidelines for drinking water of $<10 \mathrm{mg} / \mathrm{L}$ (DWAF 1996a).

Phosphate

Phosphate was not detected in Vondo and Albasini Dams during both the wet and dry seasons. Phosphate though a critical element in determining the trophic status in water impoundments, could therefore not be used for that purpose in this study. The detection limit of the instrument was $0.2 \mathrm{mg} / \mathrm{L}$. It means phosphates in the two dams were below this value. The SA guideline for phosphate in water systems that reduces the likelihood of algal and plant growth is $5 \mu \mathrm{g} / \mathrm{L}$ (DWAF 1996c). Guideline for unpolluted water is $0.05 \mathrm{mg} / \mathrm{L}$. USEPA (1986) recommended total phosphorus of not more than $0.1 \mathrm{mg} / \mathrm{L}$ for streams which do not empty into reservoirs, not more than $0.05 \mathrm{mg} / \mathrm{L}$ for streams discharging into reservoirs and not more than $0.025 \mathrm{mg} / \mathrm{L}$ for reservoirs.

\section{DO and BOD}

The DO values of Vondo and Albasini Dams from October 2003 to October 2004 varied from 5.2 to $5.7 \mathrm{mg} / \mathrm{l}$, and 4.0 to $6.0 \mathrm{mg} / \mathrm{L}$, respectively (Fig. $5 \mathrm{a}$ ). These are within the acceptable limit for aquatic ecosystem of greater than $5 \mathrm{mg} / \mathrm{L}$ (DWAF 1996c) for Vondo Dam. However, for Albasini Dam the DO values are less or fall within the acceptable limit. Dissolved oxygen is an indication of how polluted the water is and how well the water can support aquatic plants and animals. High dissolved oxygen indicates better water quality. If dissolved oxygen levels are too low, some fish and other organisms may not be able to 


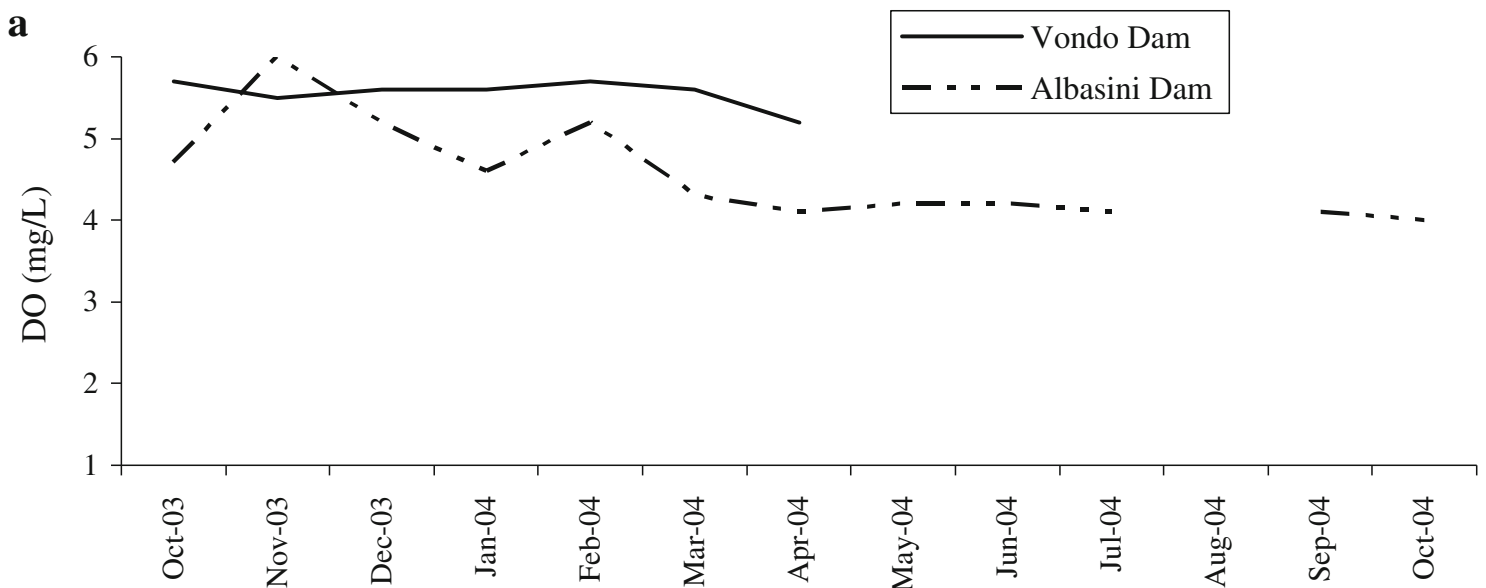

Time (months)

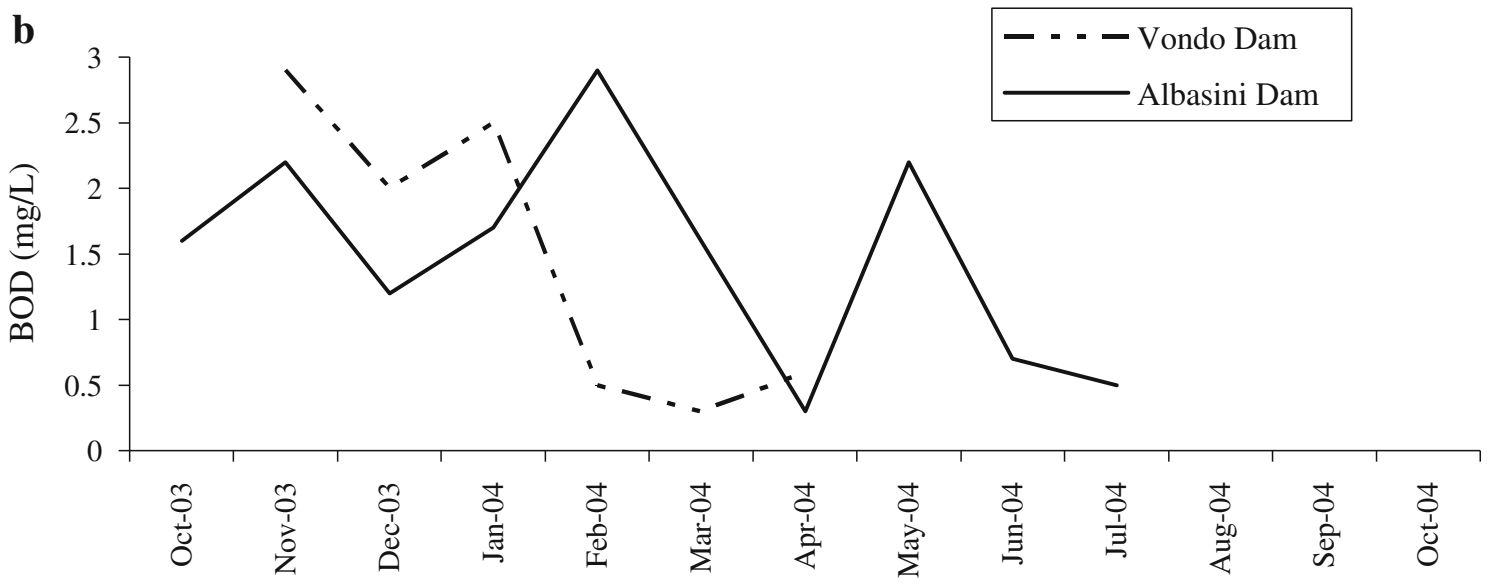

Time (months)

Fig. 5 a DO concentrations for raw water from Vondo and Albasini Dams from October 2003 to October 2004. b BOD concentrations for raw water from Vondo and Albasini Dams from October 2003 to October 2004

survive. Comparison of DO levels between the two dams reveals that in raw water, Vondo Dam values were higher than Albasini Dam values by about $1 \mathrm{mg} / \mathrm{L}$.

Relatively high values of DO for Vondo Dam are in equilibrium with the atmosphere and are a by-product of photosynthesis because oxygen production from photosynthesis contributes to an increase in dissolved oxygen levels. Because of the abundance of oxygen there is low BOD and the species diversity in the dam is high.

During October 2003, January 2004 and from March to October 2004 the values of DO for Albasini Dam dropped below $5 \mathrm{mg} / \mathrm{L}$. Dissolved Oxygen concentration below $5 \mathrm{mg} / \mathrm{L}$ adversely affect aquatic life. Low DO values may be caused by excessive supply of aquatic plant nutrients that stimulate the growth of algal blooms. Relatively high concentration of nitrate in Albasini Dam makes the dam water to tend towards eutrophic status. This stimulates the growth of algal blooms, which die and decompose. The process of decomposition removes oxygen from the water, resulting in the need for high priority level of conservation.

Since the levels of TSS from both Vondo and Albasini Dams are low, the low levels of DO during some months may be caused by aquatic plants nutrients. If TSS is high, the level of photosynthesis would be reduced due to poor light penetration and the level of oxygen produced as by product would be low.

BOD values for Vondo and Albasini Dams from October 2003 to October 2004 both varied between 0.3 and $2.9 \mathrm{mg} / \mathrm{L}$ (Fig. 5b). These fall above and within the acceptable level of BOD for the protection of aquatic ecosystems of less than $2 \mathrm{mg} / \mathrm{L}$ (DWAF 1996c). BOD values for Vondo Dam from October-December 2003 are above the recommended limit possibly due to the addition of excess nutrients such as nitrates for agriculture during 
the rainy season (Fig. 5b). Similarly, the BOD values for Albasini Dam are above the recommended limit during some months. These, however, may not have affected the aquatic ecosystem particularly when the DO levels were high during the same periods. This requires a future routine monitoring of BOD versus DO to ensure that the level of BOD is not higher than the level of DO. This normally happens in eutrophic water impoundments. The high BOD values reduce the species diversity especially in eutrophic impoundments. Some of the aquatic organisms such as fish and crabs cannot survive under anaerobic conditions. Thus, other than routine monitoring, high priority conservation is essential.

USEPA shows that there is no limit for potassium in aquatic ecosystem (SRC Analytical Laboratories 2005). Therefore, high concentration of potassium does not necessarily have negative impact on aquatic plants because potassium levels do not limit them in their ability to produce nutrients through photosynthesis, as it is the case for nitrogen and phosphorus. High potassium concentrations in Albasini Dam are likely to be from runoff from irrigated agricultural lands, and from domestic wastes.

The potassium concentrations for final water from Vondo and Albasini WTPs ranged between $0.12-1.58 \mathrm{mg} / \mathrm{L}$ and $0.06-2.74 \mathrm{mg} / \mathrm{L}$ from October 2003 to October 2004, respectively (Fig. 6a). The South African potassium quality guideline for drinking water is less than $25 \mathrm{mg} / \mathrm{L}$ (DWAF et al. 1999). The concentration of potassium for raw water from Vondo Dam and final water from Vondo and Albasini WTPs do not have negative impacts on human health since the levels of potassium are within the recommended limits.

The magnesium concentrations in raw water from Vondo and Albasini Dams from October 2003 to October 2004 ranged from 0.14 to $3.08 \mathrm{mg} / \mathrm{L}$ and 7.98 to $18.40 \mathrm{mg} / \mathrm{L}$, respectively (Fig. 6b). The SA magnesium concentration guideline for unpolluted fresh water is less than $10 \mathrm{mg} / \mathrm{L}$ (DWAF 1996a). The magnesium concentrations in raw water from Vondo Dam during October 2003 to October 2004 were within the recommended limit. High concentrations of magnesium exceeding the SA guideline for unpolluted fresh water were detected from October 2003 to April 2004 and June-August 2004 for Albasini Dam. USEPA gives the limit for magnesium in aquatic ecosystems as $200 \mathrm{mg} / \mathrm{L}$ (SRC Analytical Laboratories 2005) and thus these high concentrations of magnesium may not have any serious impact on the aquatic ecosystems. Like potassium and possibly due to the same reasons, magnesium concentrations in Albasini Dam are high compared to Vondo Dam.

The mean concentrations of magnesium in final water from Vondo and Albasini WTPs from October 2003 to October 2004 varied from 0.41 to $2.93 \mathrm{mg} / \mathrm{L}$ and 7.51 to $17.59 \mathrm{mg} / \mathrm{L}$, respectively (Fig 6b). The values are within
Fig. 6 a Potassium concentrations for raw water from Vondo and Albasini Dams and final water from Vondo and Albasini WTPs from October 2003 to October 2004. b Magnesium concentrations for raw water from Vondo and Albasini Dams and final water from Vondo and Albasini WTPs from October 2003 to October 2004. c Calcium concentrations for raw water from Vondo and Albasini Dams and final water from Vondo and Albasini WTPs from October 2003 to October 2004. d Sodium concentrations for raw water from Vondo and Albasini Dams and final water from Vondo and Albasini WTPs from October 2003 to October 2004

the recommended limit for drinking water of less than $30 \mathrm{mg} / \mathrm{L}$ (DWAF et al. 1999) and do not have adverse effects on human health. Magnesium is essential nutritional element needed for normal functioning of the muscles. The total dietary intake is about $250 \mathrm{mg} /$ day in adults (DWAF 1996a). Magnesium concentrations above $70 \mathrm{mg} / \mathrm{L}$ impart bitter taste to water (DWAF et al. 1999).

Calcium concentrations for raw water from Vondo and Albasini Dams from October 2003 to October 2004 ranged from 0.29 to $2.97 \mathrm{mg} / \mathrm{L}$ and 0.95 to $19.87 \mathrm{mg} / \mathrm{L}$, respectively (Fig 6c). The SA calcium guideline for unpolluted fresh water is $<10 \mathrm{mg} / \mathrm{L}$ (DWAF et al. 1999). The values of calcium in Vondo Dam were within the acceptable limit. The calcium concentration was within the acceptable limit in Albasini Dam during October 2003 to December 2003 and October 2004. From January to September 2004 the calcium concentrations exceeded the SA recommended limit. However, according to USEPA there is no limit for calcium in aquatic ecosystem (SRC Analytical Laboratories 2005).

Calcium concentrations in Albasini Dam may be occurring naturally or may result from the leaching of soil and other natural sources. Calcium also serves an important role in the health of water bodies. Therefore, high calcium concentrations in Albasini Dam do not have effect on aquatic ecosystem because in natural water calcium is known to reduce the toxicity of many chemical compounds on fish and other aquatic life.

Calcium concentrations for final water from Vondo and Albasini WTPs from October 2003 to October 2004 ranged from 0.22 to $2.46 \mathrm{mg} / \mathrm{L}$ and 1.52 to $17.07 \mathrm{mg} / \mathrm{L}$, respectively (Fig. 6c). The SA calcium guideline for drinking water is $32-80 \mathrm{mg} / \mathrm{L}$ (DWAF et al. 1999). The calcium concentrations were within the acceptable limit for both the WTPs. This means that the plants, particularly the Albasini WTP, are operated efficiently.

Sodium concentrations in raw water from Vondo and Albasini Dams from October 2003 to October 2004 ranged from 1.13 to $7.19 \mathrm{mg} / \mathrm{L}$ and 1.61 to $18.64 \mathrm{mg} / \mathrm{L}$, respectively (Fig. 6d). The SA guideline for sodium in unpolluted water is $2-3 \mathrm{mg} / \mathrm{L}$ (DWAF et al. 1999). Sodium concentrations in Vondo Dam from October-December 2003 were within the recommended limit. The sodium concentrations from January-September 2004 were above the 


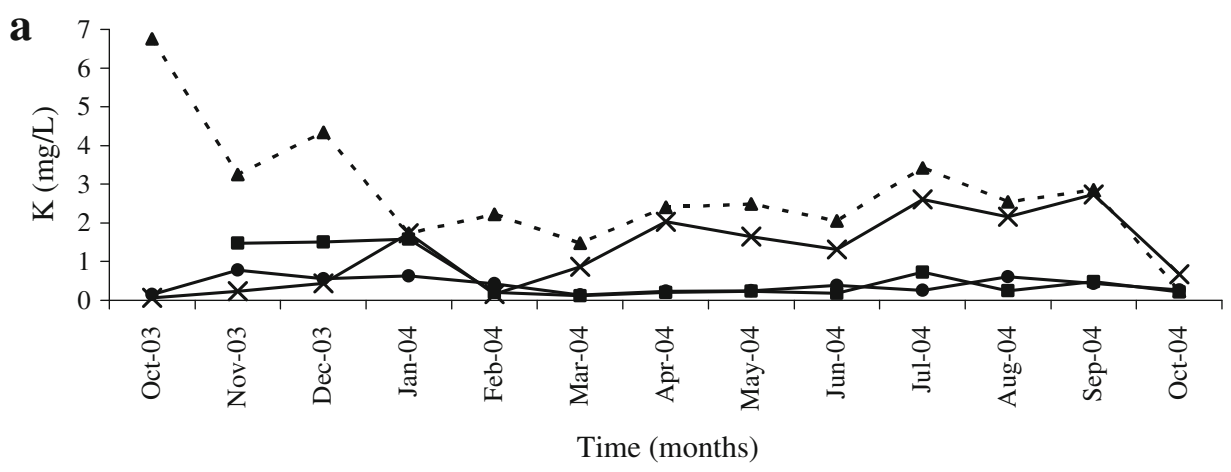

- - - - - Albasini Dam $\longrightarrow$ Vondo Dam $\longrightarrow$ Vondo WTP $\longrightarrow$ Albasini WTP

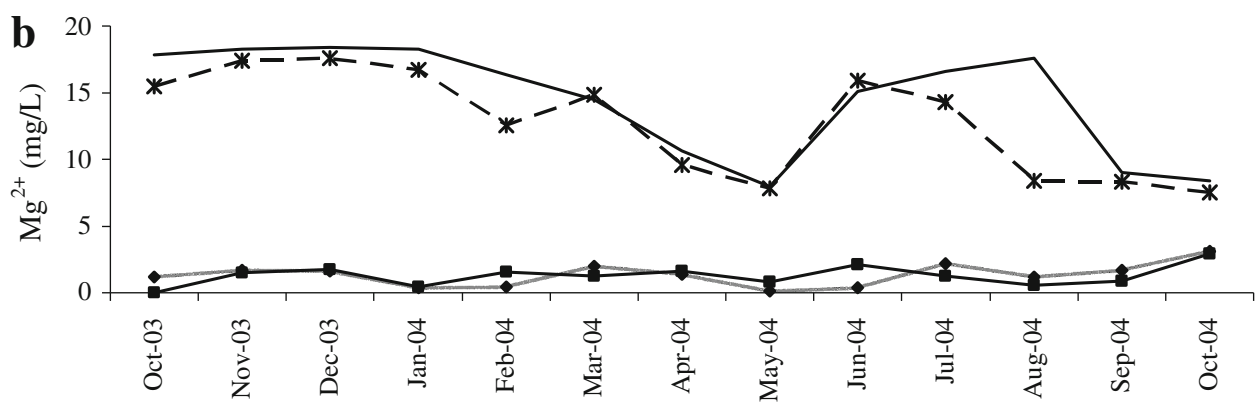

Time (months)

$\longrightarrow$ Vondo Dam $\longrightarrow$ Vondo WTP — Albasini Dam — * - Albasini WTP

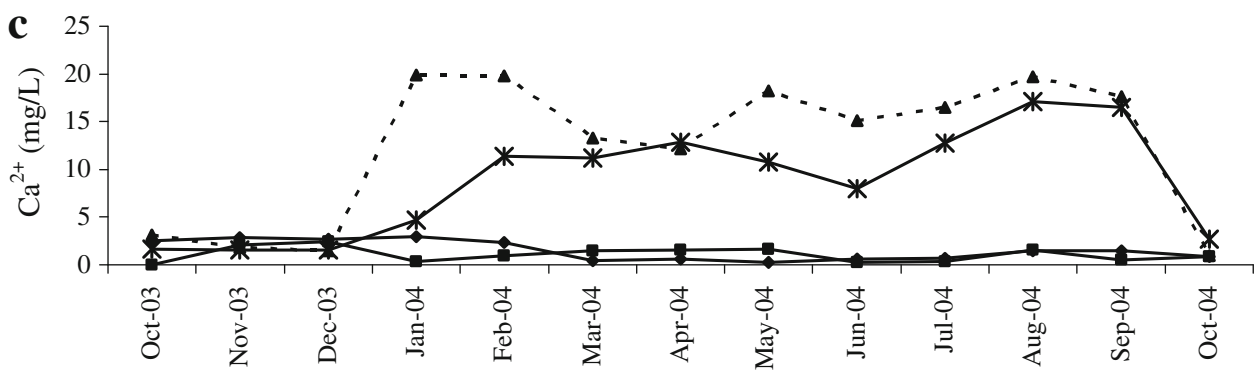

Time (months)

- - - - A Albasini Dam $\longrightarrow$ Vondo Dam $\longrightarrow-$ Vondo WTP $\longrightarrow$ Albasini WTP

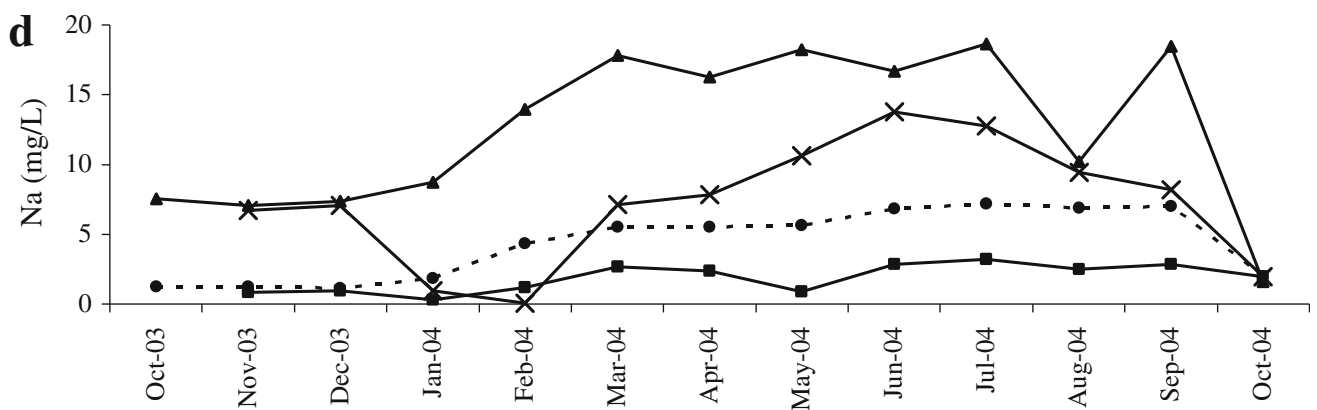

Time (months)

$\because \bullet-\cdot$ Vondo Dam $\longrightarrow$ Vondo WTP $\longrightarrow$ Albasini Dam $\longrightarrow$ Albasini WTP 


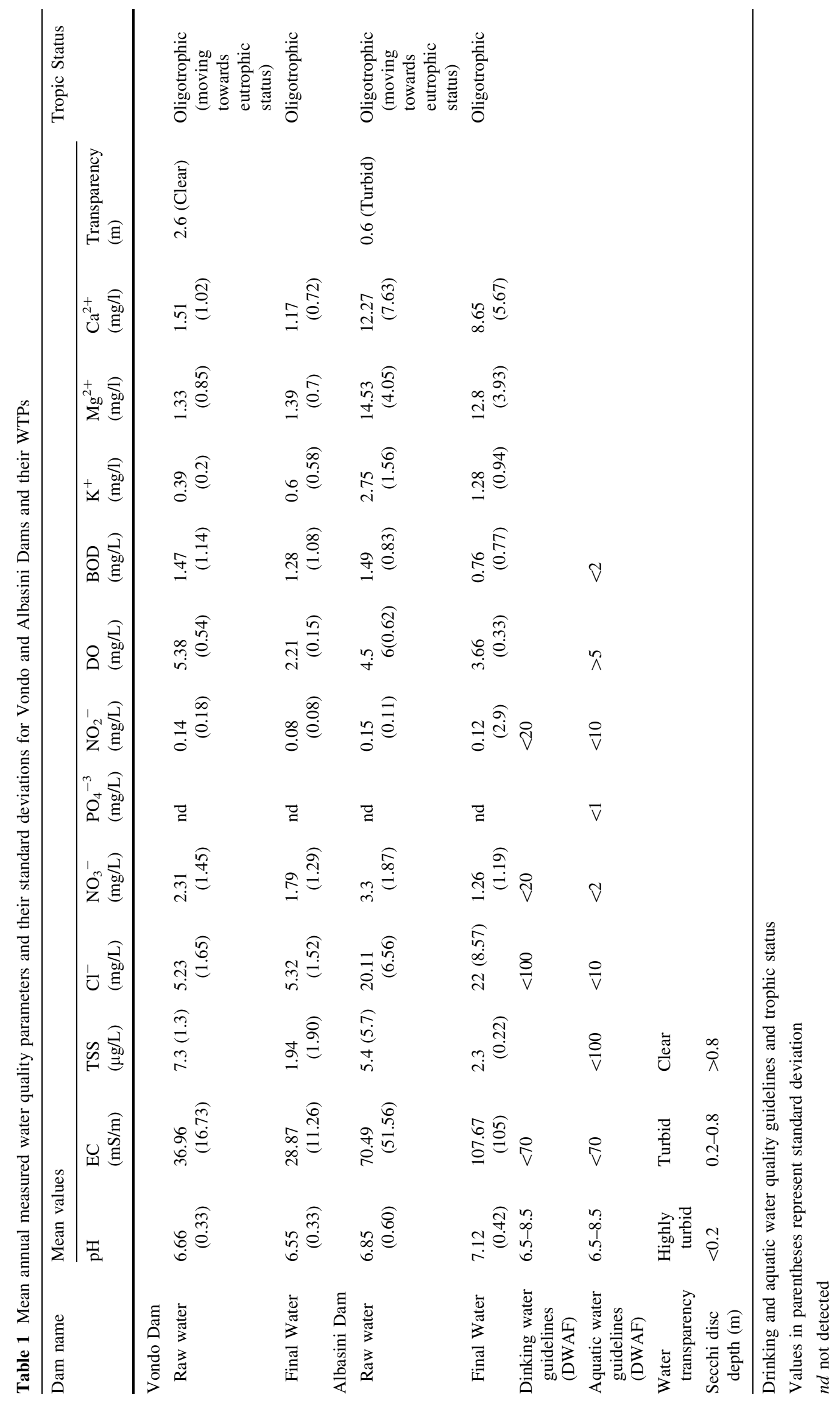


recommended SA limit. Sodium concentrations in Albasini Dam exceeded the SA guidelines for unpolluted fresh water from October 2003 to September 2004. High concentrations of sodium from Albasini Dam may be caused by domestic wastewater; this is in part due to the addition of table salt (sodium chloride) to foods. Sodium concentrations are elevated in runoffs or leachate from irrigated soils. Some parts of the Soutpansberg Mountain where Luvuvhu River on which Albasini Dam is found originates are known to have concentrations of sodium chloride.

Like potassium, sodium levels do not directly limit aquatic plants in their ability to produce nutrients through photosynthesis, as they are by nitrogen and phosphorus. USEPA gives the limit for aquatic ecosystems as $300 \mathrm{mg} / \mathrm{L}$ and thus the values measured in both Vondo and Albasini Dams may not have any significant impact on the aquatic ecosystems.

The sodium concentrations in final water from Vondo and Albasini WTPs from October 2003 to October 2004 ranged from 0.30 to $3.19 \mathrm{mg} / \mathrm{L}$ and 0.07 to $13.77 \mathrm{mg} / \mathrm{L}$, respectively (Fig 6d). The concentrations of sodium in drinking water are within the recommended limit of $<100 \mathrm{mg} / \mathrm{L}$ (DWAF et al. 1999). The sodium concentrations in final water from October 2003 to October 2004 in Vondo and Albasni WTPs were within the acceptable limit of less than $100 \mathrm{mg} / \mathrm{L}$ (DWAF et al. 1999). Thus the water from both the WTPs is safe for drinking.

Trophic status and water quality of Vondo and Albasini Dams

Table 1 gives a summary of the mean annual values of the measured water quality parameters and their standard deviations for Vondo and Albasini Dams and the WTPs; the DWAF et al. (1999) guidelines for both drinking water and aquatic life, and the trophic status of both the dams. For Vondo Dam, most if not all the measured water quality parameters in both raw and final water were within the recommended ranges. Therefore it can be concluded that the water from Vondo Dam was dominantly Oligotrophic. The exception was the level of nitrates especially in the raw water, which was slightly above the recommended limit for aquatic ecosystems of $2 \mathrm{mg} / \mathrm{L}$. The slightly high concentration of nitrates could possibly have been due to land use developments in the catchment. This may suggest that although the water quality status of the dam was within acceptable management limits, it could move towards full eutrophic status in future, due to increased land use development.

The mean annual measured water quality parameters for Albasini Dam (Table 1) show that unlike Vondo Dam, the electrical conductivity exceeded the recommended guideline for drinking water while additionally, the nitrate and chloride exceeded the recommended guidelines for aquatic life. Mean annual water transparency $(0.6 \mathrm{~m})$ for Albasini Dam also showed that the water is turbid. The trophic status for Albasini Dam can be classified as a mixture of oligotrophic and eutrophic states. However, since some of the parameters were within the recommended guidelines and given that phosphorus was not detected and nitrate was very close to the recommended value, Albasini Dam can be considered to be dominantly oligotrophic. Therefore water quality for both Albasini and Vondo Dams is mostly suitable for aquatic and domestic water uses (human consumption). This also means that there is no impact of eutrophication on Albasini and Vondo WTPs.

Related studies have been reported elsewhere on the trophic status of aquatic ecosystems (Rosas et al. 1993; Nasrollahzadeh et al. 2008). The trophic status of the Caspian Sea was investigated based on water quality parameters and phytoplankton diversity (Nasrollahzadeh et al. 2008). In this case high trophic status was attributed to the introduction of alien species in the sea. A study by Rosas et al. (1993) used algal community and water quality parameters to assess the trophic status of Lake Patzcuaro, Mexico. Spatial and temporal variability in both physical and biological conditions made it difficulty to assign a specific trophic status for the lake. However, algal community alone pointed to an ecosystem that is generally in mesotrophic condition.

\section{Conclusion}

This study in which trophic status classification has been inferred from TSS, $\mathrm{pH}$, nitrates, water transparency, BOD and DO among other water quality parameters has inferred dominance of oligotrophic status for both Vondo and Albasini Dams as similarly done in a study by DWAF (2002-2003). The research also indicates that Albasini Dam and to a lesser extent Vondo Dam could be moving towards eutrophic status. The research has also shown that the oligotrophic status of the water impoundments results in minimum water quality problems, thus potable treatment can be achieved at low cost.

The study recommends that to maintain or sustain the oligotrophic status for both Vondo and Albasini Dams, the farmers must strictly apply only sufficient nutrients to be absorbed by the plants to avoid dissolution and leaching by runoff to surface and groundwater systems. The actual source(s) of high levels of nitrate from both Vondo and Albasini Dams observed during high flow (rainy season) and low flow (dry season) needs to be investigated. It may be important to use much more sensitive equipment that can detect much lower concentrations of phosphorus in order to make much more reliable and accurate decision on 
trophic status of the water impoundments. This is because phosphorus is the most limiting nutrient for deciding on the trophic status of the water impoundments.

Acknowledgments The authors wish to acknowledge the Chemistry department of the University of the Witwatersrand for allowing us to analyze the water samples in their laboratory. Authors are indebted to Water Research Commission (WRC) for financially supporting water samples analyses under WRC project grant number K5/1343/2-3. Lastly, authors wish to acknowledge Ms. Rachel Makungo who assisted with the plotting of the results on excel spreadsheet and editing of the write-up.

\section{References}

Davies D, Day J (1998) Vanishing waters. University of Cape Town Press, Capetown, pp 152-205

DAWM (1985-1994) Water quality parameters: river assessment monitoring project: Kentucky water watch. Division of ambient water Monitoring Database. http://www.kywater.org/ww/rap/ rmd.htm

DWAF, DoHealth, WRC (1999) Quality of domestic water supplies. Assessment guide, vol 1. South African Departments of Water Affairs and Forestry, Department of Health and Water Research Commission

DWAF (1996a) South African water quality guidelines. Domestic use, vol 1. 2nd edn. Department of Water Affairs and Forestry

DWAF (1996b) South African water quality guidelines. Agricultural use: livestock watering, vol 5. 2nd edn. Department of Water Affairs and Forestry

DWAF (1996c) South African water quality guidelines. Aquatic ecosystems, vol 7. 1st edn. Department of Water Affairs and Forestry

DWAF (2002-2003) National Eutrophication Monitoring Programme. http://www.dwaf.pmv.gov.za/iwqs/Eutrophication/NEMP/nemp/ nempdam.htm

DWAF (2003) Reconciliation and development of water supply and sanitation programme: Vondo water supply schemes, South African Department of Water Affairs and Forestry

Fatoki OS, Gogwana P, Ogunfowokan AO (2003) Pollution assessment in the Keiskamma River and the impoundment downstream. Water SA 29(2):183-187

Freedman B (1995) Environmental Ecology: the ecological effects of pollution, disturbance, and other stresses, 2nd edn. Academic Press Inc, San Diego

Giordani G, Zaldivar JM, Viaroli P (2009) Simple tools for assessing water quality and trophic status in transitional water ecosystems. Ecol. Indicat 9(5):982-991

Harding WR (2008) The Determination of annual phosphorus loading limits for South African dams, WRC Report No 1687/1/08, Water Research Commission
Horiba International Co-operation (2003) Water Quality, Temperature and Gloss Measurement. http://www.global.horiba.com. analy-e/u-20-series/u-20-series/02.htm

Liou YT, Lo SL (2005) A fuzzy index model for trophic status evaluation of reservoir rivers. Water Res 39(7):1415-1423

Mamali MA (2007) Assessment of the trophic status of Vondo and Albasini Water Impoundments. MSc Dissertation, University of Venda

Morgan RPC (1990) Erosion and soil conservation. Longman Scientific and Technical, England

Nasrollahzadeh HS, Pin ZB, Foong SY, Makhlough A (2008) Trophic status of the Iranian Caspian Sea based on water quality parameters and phytoplankton diversity. Contin Shelf Res 28(9):1153-1165

NIWR (1985) The limnology of Harbeessport Dam. SA National Scientific Programmes, Report No. National Institute for Water Research 110

Noble RG, Hemens J (1978) Inland water ecosystem in South Africa: a review of research needs, South African National Scientific Programmes, Report No. 34

Rosas I, Velasco A, Belmont R, Baez A, Martinez A (1993) The algal community as indicator of the trophic status of Lake Patzcuaro. Mexico Environ Pollut 80(3):255-264

Sager L (2009) Measuring the trophic status of ponds: relationships between summer rate of periphytic net primary productivity and water physic-chemistry. Water Res 43(6):1667-1679

SRC Analytical Laboratories (2005) Research Resource Centre, Saskantoon. http://www.city.saskatoonsk.ca/org/water/treat ment/quality.details.asp

Toerien DF, Hyman KL, Bruwer MJ (1975) A preliminary trophic status classification of some South Africa impoundments. Water SA. 1(1):15-23. http://www.wrc.org.za/Lists/Knowledge\%20 Hub\%20Items/Attachments/6128/0009\%20abstract.pdf

Toerin DF (1974) South African eutrophication problems, a perspective paper presented at the IWPC conference. Salisburg, Rhodesia

USEPA (1986) United States Environmental Protection Agency for Water quality standards. http://www.epa.gov/maia/htm/eutrop/ html

Van Ginkel CE (2001) Eutrophication. Institute for environmental studies. The University of Texas and Dallas

Videtich PE, Erik JC (2002) Living with Great Lakes. Grand Valley State University. http://www.gvsu.edu/wri/education/manual/ conductivity.htm

Walmsley RD, Toerin DF, Steyn DJ (1978) Eutrophication of four Transvaal dams. Water SA. 4(2):61-75 (15)

Water Research Commission (WRC) (2000) Perspective on eutrophication of surface waters: Policy/Research Needs in South Africa, Report No. KV129/00, WRC Pretoria

Wendt-Rasch L, Van den Brink PJ, Crum SJH, Woin P (2004) The effects of a pesticide mixture on aquatic ecosystems differing in trophic status: responses of the macrophyte Myriophyllum spicatum and the periphytic algal community. Ecotoxicol Environ Safe 57(3):383-398 